\title{
Control Strategies of Power and Power Factor using PID Controller in Hybrid Energy System
}

\author{
Bindhu V.S, D.M. Mary Synthia Regis Prabha
}

\begin{abstract}
Now a days maximum rise of power can be done by the usage of wind, solar and diesel system. To get reliable electricity supply and to control the interruption and contingency hybrid power systems are used. The hybrid systems are more advantageous because both the wind and solar are renewable energies which is more convenient to the environment. The work presented in this paper consists of a combination of a wind system , a PV system and an AC load with a back up of battery source and a diesel generator. Inorder to reduce the transmission cost this system is applicable and it can be used in remote areas. PID controller with PLL technique is used to maintain the power factor constant even when one of the source is in OFF condition. The ON/OFF condition is given manually on the input side and accordingly the energy sources will produce the voltage/current output thereby power factor is maintained constant with the irradiance and temperature. One of the advantage of this system avoids penalty by maintaining the power factor constant.
\end{abstract}

Key Words--- PID Controller technique, PV system, PLL technique, Wind System Permanent Magnet SG, Boost Converter.

\section{INTRODUCTION}

To construct power system in low level places is a difficult task due to the high transmission cost also in the foresty land grounding problems occur since there are so many hilly areas. In other side natural resources are available in huge quantity as well as for the construction of self acting supply system definite reliable sources are required. The energy storage device named diesel generator was the accurate solution for it. Maintenance of the system is not necessary in the remote areas. Regarding this hybrid systems survey for different systems were stated below $^{[4]}$.This paper proposes that along with the hybrid system power electronic devices are used for the control operations ${ }^{[5]}$.To manage the power, voltage and frequency the wind and diesel based system are used along with the doubly fed induction generators. [6] [" ${ }^{[7]}$ Time frame based control algorithm are used with wind-diesel system. ${ }^{[8]}$ To regulate the voltage and frequency synchronous generator along with diesel generators are used in the hybrid system.

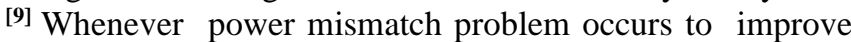
the efficiency and reduce the size battery with an ultra capacitor is proposed ${ }^{[\mathbf{1 0 ]}}$.Several simulation studies for the hybrid systems are also effective and various controllers are designed and simulated for the regulation of frequency ${ }^{[11]}$.

Revised Manuscript Received on February 05, 2020.

* Correspondence Author

Bindhu V.S, Assistant Professor, EEE, Noorul Islam Centre for Higher Education,bindhuvs2003@gmail.com

Dr.D.M. Mary Synthia Regis Prabha, Associate Professor, EEE, Noorul Islam Centre for Higher Education,regisprabha@gmail.com

(c) The Authors. Published by Blue Eyes Intelligence Engineering and Sciences Publication (BEIESP). This is an open access article under the CC BY-NC-ND license (http://creativecommons.org/licenses/by-nc-nd/4.0/)
Diesel-wind-photovoltaic system were studied and analyzed with the performance of different types of generators ${ }^{[12]}$.Variation of wind and failure of any element leads to the calculation of reliability ${ }^{[13]}$.Wind energy with PMSG is incorporated and is connected to an inverter ${ }^{[14]}$. To increase the maximum power and efficiency from the wind energy systems many algorithms were implemented. ${ }^{[15]}$ MPPT algorithms were used for the replacement of sensors. ${ }^{[16]}$ To control the power quality problems MPPT using perturb and observe algorithms are used.

This paper focuses a independent hybrid system with the incorporation of wind, solar and diesel system to maintain the constant power factor. ${ }^{[17]}$ For the conversion of variable dc into a fixed dc voltage in the PV system power electronic converters are used also the boost converter converts dc-dc voltage and further an dc to ac conversion are done in inverter. Thus a output of constant dc voltage occured in the boost converter. ${ }^{[\mathbf{1 8 ]}}$ The stable output power can be obtained from the wind system using pitch control. If the speed of the wind is lesser when compared with the rated wind speed then the output power can be limited by using the pitch angle. The best method for the design of pitch control system is done by using a PID controller. ${ }^{[19]}$ Power electronic converters are used to extract electrical energy from wind and its response and characteristics were good. Stable and unstable are the two types of wind energy conversion system. Fixed speed type produces the peak output only at one speed. Variable speed type produces the peak output at different speed values and it has better efficiency, power quality than stable speed type wind energy conversion system. Cost reduces because PMSG is straightaway coupled to the wind turbine.Wind speed is not constant therefore the voltage output is also quite changing. The voltage output is low for lower wind speed and voltage output is high for higher wind speed. Therefore to make the sustained voltage output a boost converter is considered. The usage of battery is necessary in the absence of renewable energy source and grid support and the battery was not up to the capacity to supply the power demand. Therefore for the efficient flow of power diesel generator is coupled with the grid to meet the load demand.

\section{PROPOSED TOPOLOGY}

The scheduled system is incorporated with solar and wind energy as the primary source and a battery system as a back up of diesel generator. [20] No maintenance is required because the sources are available in free of charge and user friendly for the environment to generate power. During rainy season, cloudy period and at night the power generation is absent therefore in order to increase the efficiency this proposed method can be adapted. 
In the stormy weather, sufficient amount of solar energy is not produced but wind energy produces more energy than solar system. Advantage of this combined system is used to compensate the issues of power related problems. In this proposed process wind energy together with permanent magnet synchronous generator is built within and an ac output is generated using AC-DC converter then the ac output is now converted into DC. Similarly the PV system also produces an DC output. Boost converter is connected in the output of wind and solar system so as to increase the voltage output.

The diesel generator converts the ac output into DC by the use of converter. To interconnect all the three outputs from the hybrid sources a PID controller is used. The error value is measured continuously in the PID controller. The inverter used transforms the DC output voltage coming out from the solar, wind and diesel as ac voltage output. A three phase transformer is interconnected to the circuits to transform the three phase ac output power to the load/grid. This topology mainly used for reducing the penalty as per the switching done manually in the circuit. When any one of the source is not available power factor is maintained constant.

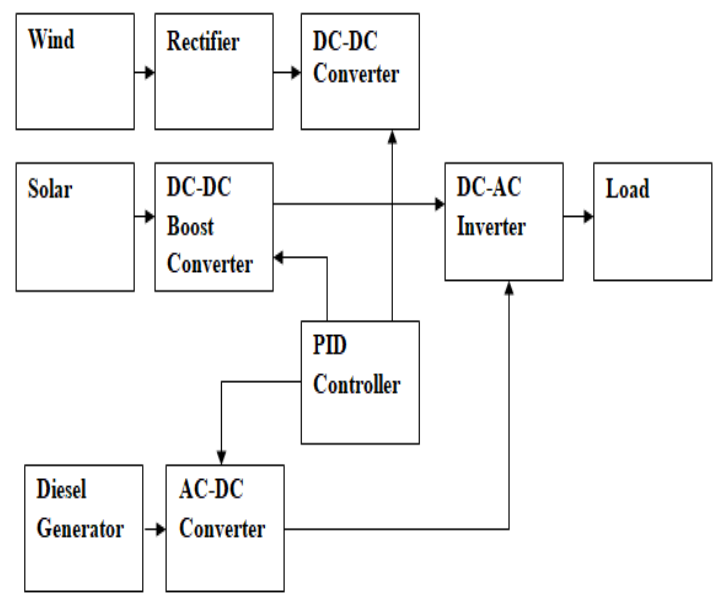

Fig 1.Proposed Block Diagram

\section{BASIC COMPONENTS OF HYBRID ENERGY SYSTEMS}

The basic components used in this system are solar, wind, diesel generator and a battery source. These components are interconnected and the solar output, wind systems outputs are then given to the input of a boost converter to get the maximum output voltage. The boost converter output is then connected to a PID controller and by the use of inverter dc output is connected into ac by using PLL technique. Even when any one of the source is not available the power is maintained constant.

\section{Modelling of PV cell}

[21] The conversion of electrical energy from sunlight energy is obtained from the photovoltaic solar system. A simple concept of photovoltaic system is shown in the below fig.2.

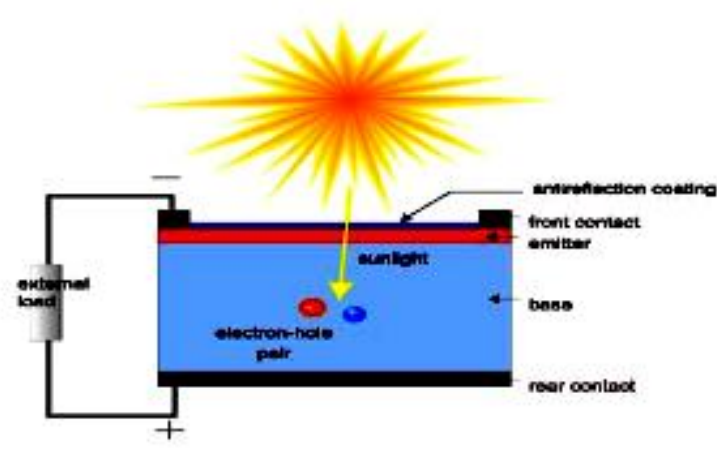

Fig 2.Concept of photovoltaic

A typical solar battery includes a current source $\left(\mathrm{I}_{\mathrm{L}}\right)$, a semiconductor diode, a resistance were connected in parallel and a resistance in series. ${ }^{[20]}$ Based on the semiconductor used and the built up technology this PV cell produce an open circuit voltage about 0.5 to 0.7 volts. In order to produce high voltage and high current output the solar batteries are arranged in series and parallel to form a module. The fig. 3 represents a single diode equivalent circuit of the solar battery.

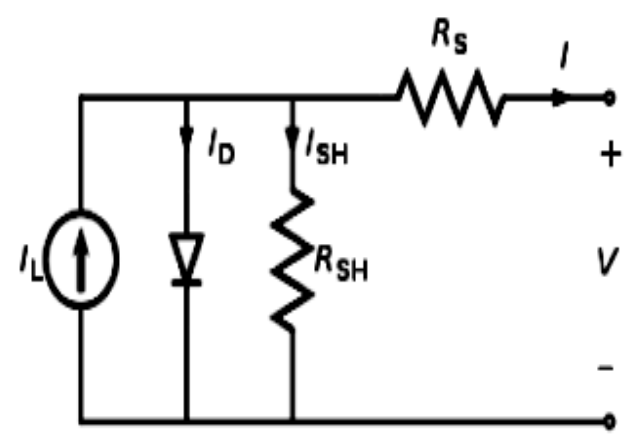

Fig.3. A PV cell equivalent model using a single diode

For a single diode PV cell as per the relationship of current and voltage of a solar cell led to gave a mathematical model. Depending upon the solar irradiation and temperature the PV array is designed and if the solar irradiation varies then the output power changes also the voltage output varies with respect to temperature. The mathematical model for PV array is mentioned below.

Solar cell output current is found out from the fig.3

$I=I_{L}-I_{D}-I_{g h \ldots \ldots \ldots \ldots} \ldots \ldots$

$I_{L^{---}-\text {current from the incident light }}$

$I_{D} \times m$ diode saturation current

$I_{g h m \times}$ shunt resistance current

The Schottky diode equation can be expressed as $I_{D}=\left\{\exp \left[\frac{V_{D}}{\eta V_{T}}\right]-1\right\} \ldots . .2$

Temperature Equivalent voltage is given as $V_{T}=\frac{K T}{q} \ldots . .3$ 
Boltzmann's constant represents as K, q denotes electron charge, $I_{d}$ denotes the diode saturation current, $T$ denotes the PV cell temperature.

$I=I_{L}-I_{0}\left\{\exp \left[\frac{V_{D}}{\eta V_{T}}\right]-1\right\}-\frac{V+I R_{s}}{R_{g h}} \ldots \ldots$

Equation no.(1)-(4) represents the expressions for solar cells used. ${ }^{\text {[21] }}$

\section{Modelling of wind system}

[22] Basically the wind power is termed as the transformation of kinetic to mechanical energy output. Normally the turbine blades receives this kinetic and transforms into mechanical and electrical output is produced again when this mechanical energy is converted. From the rotor blades the actual power is extracted from the difference of upstream and downstream wind powers as shown in eqn.no. 5

$P_{0}=0.5 \times($ Mass flow per second $) \times\left(V^{2}-V_{0}^{2}\right) \ldots \ldots .5$

The mechanical power is given as $\mathrm{P}_{0}$, Upstream wind velocity is given as $\mathrm{V}$, Downstream wind velocity is given as $\mathrm{V}_{\mathrm{o}}$

Mechanical power produced from the rotor is given by the eqn.no.6

$P_{0}=\frac{1}{2}\left[\rho A \frac{V+V_{0}}{2}\right]\left(V^{2}-V_{0}^{2}\right) \ldots 6$

Then eqn.no.(5)\&(6) are rearranged and written as eqn.no.7 $P_{0}=\frac{1}{2} \rho A V^{3} C_{p}=\frac{1}{2} \rho \pi R^{2} V^{3} C_{p \ldots n} 7$

Air density represents as $\rho$, Area is represented as A,R as radius, $\mathrm{V}$ as wind speed, Power coefficient as $\mathrm{C}_{\mathrm{p}}$.

The torque equation of the wind turbine is indicated below. $\tau_{\omega}=\frac{P_{w}}{\omega} \ldots x=8$

$\omega$ - indicates the rotor speed .

Equation no. (5)-(8)represents the expressions for Wind systems used [22]

\section{Diesel Generator system}

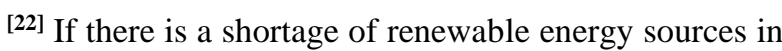
the hybrid system a diesel generator is coupled with the system to get everlasting electric supply. The power output from wind and PV cells are not sufficient to provide the supply for the load under that condition diesel generator usage was satisfactory. Some of the factors considered for the smooth operation of diesel generator includes the load variation analysis, load increase in one year and the practical difficulties arising from the interconnection of various components for the easy operation of diesel generator.

\section{Battery system}

One of the basic component of an energy storage systems are batteries. It is the electrical connection of one or more electrochemical cells in which the ions are produced due to oxidation reaction during cell operation .Self discharge of the battery takes place if the electrolyte combined with electrons because the electrons possess poor conductivity for ions. Thus the internal circuit is formed in between the electrodes. ${ }^{[3]}$

\section{SIMULATION RESULTS AND DISCUSSIONS}

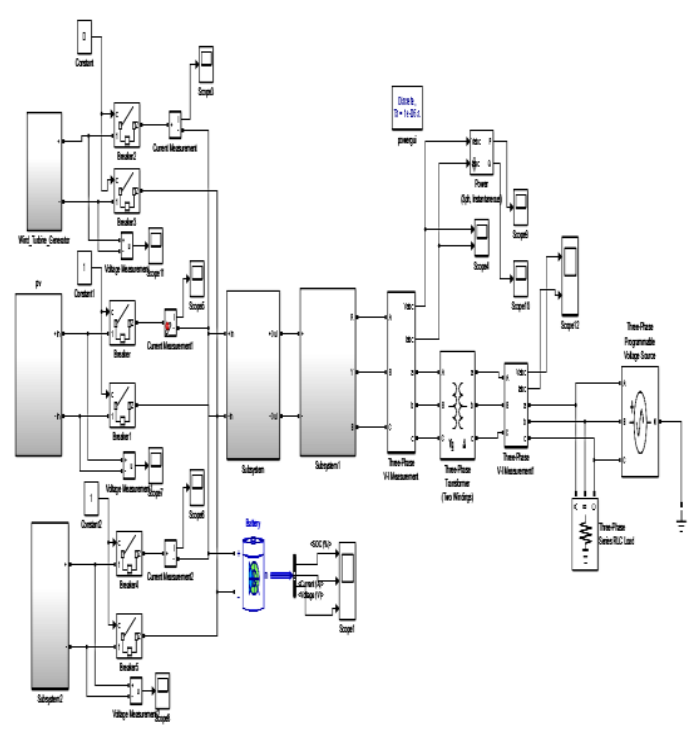

Fig.4.Simulink diagram of Hybrid Energy System

\section{EXPERIMENTAL RESULTS}

For the different wind speed corresponding wind power is obtained through the simulation are shown in table 1.

Table 1.Different Wind speed with Wind Power

\begin{tabular}{|c|c|c|}
\hline Sl.No & $\begin{array}{l}\text { Wind } \\
\text { Speed(m/s) }\end{array}$ & $\begin{array}{l}\text { Wind } \\
\text { Power(w) }\end{array}$ \\
\hline 1 & 14 & $2.07 \mathrm{E}+04$ \\
\hline 2 & 13 & $2.06 \mathrm{E}+04$ \\
\hline 3 & 12 & $2.09 \mathrm{E}+04$ \\
\hline 4 & 11 & $2.04 \mathrm{E}+04$ \\
\hline 5 & 10 & $2.03 \mathrm{E}+04$ \\
\hline
\end{tabular}

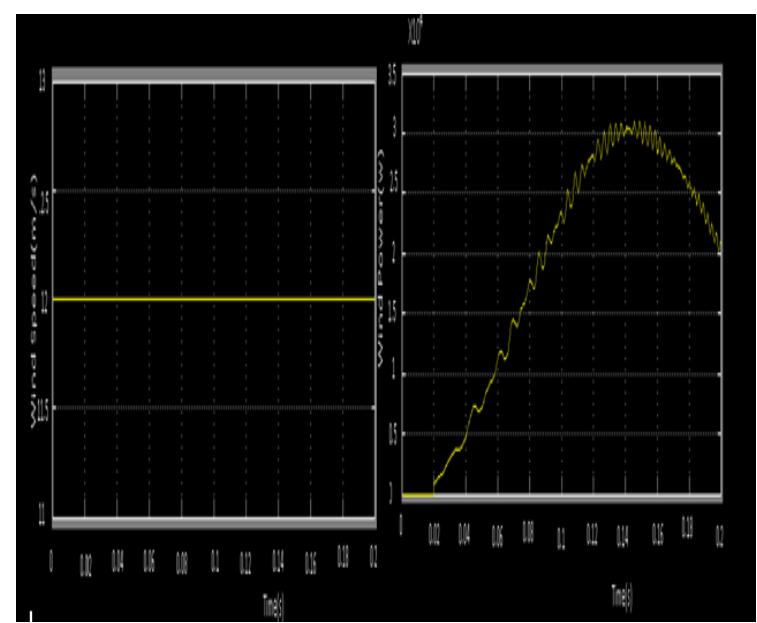

Fig.5.Wind speed 12 wind power 2.086

Fig 5.indicates the maximum wind power in (w) is achieved at a value of wind speed in $12(\mathrm{~m} / \mathrm{s})$. In the proposed hybrid system wind speed value used for the wind system is 12 .

For the varying irradiance corresponding voltage is obtained through the simulation are shown in table 2. 
Table 2.Different irradiance with Voltage

\begin{tabular}{|r|r|r|}
\hline Sl.No. & Irradiance(W/m²) & Voltage(V) \\
\hline 1 & 1000 & 642.3 \\
\hline 2 & 800 & 651.6 \\
\hline
\end{tabular}

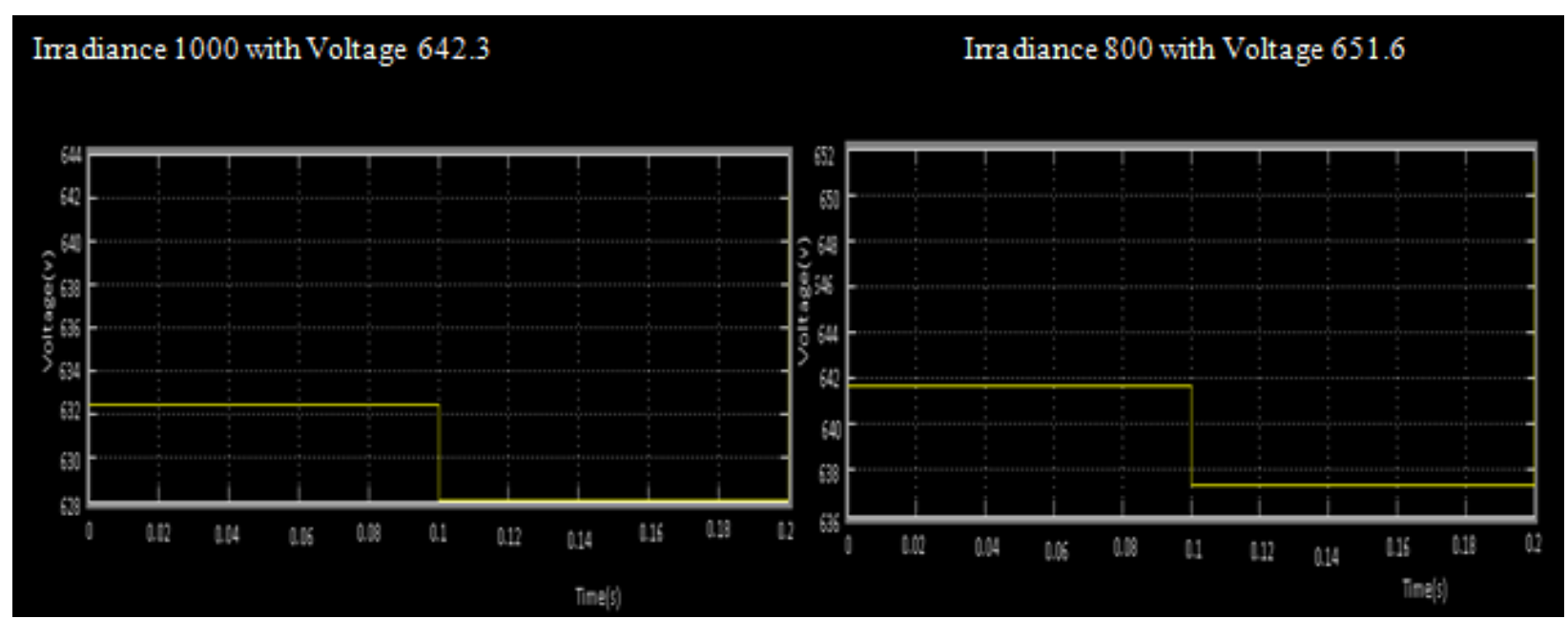

Fig. 6 Varying Irradiance with Voltage Ouput

Fig.6 represents the Output voltage for the irradiance given. In the proposed work PV system having the irradiance of $1000 \mathrm{~W} / \mathrm{m}^{2}$ is used.

In the proposed work simulated voltage and current output obtained when all the three systems are connected together are as shown below.

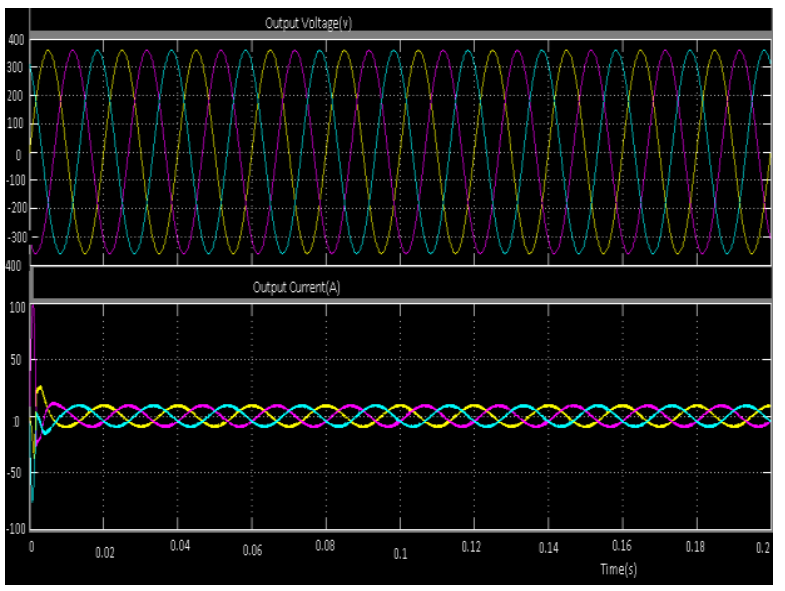

Fig .7. Voltage and Current simulation output for the proposed system

Fig.7.represents the simulated voltage and current output with respect to time is obtained when any one of the source is in OFF condition.The conditions are . i) When WindON,PV-OFF,Diesel-ON, ii) Wind-OFF,PV-ON,Diesel-ON and iii) Wind-ON,PV-ON,Diesel-OFF.

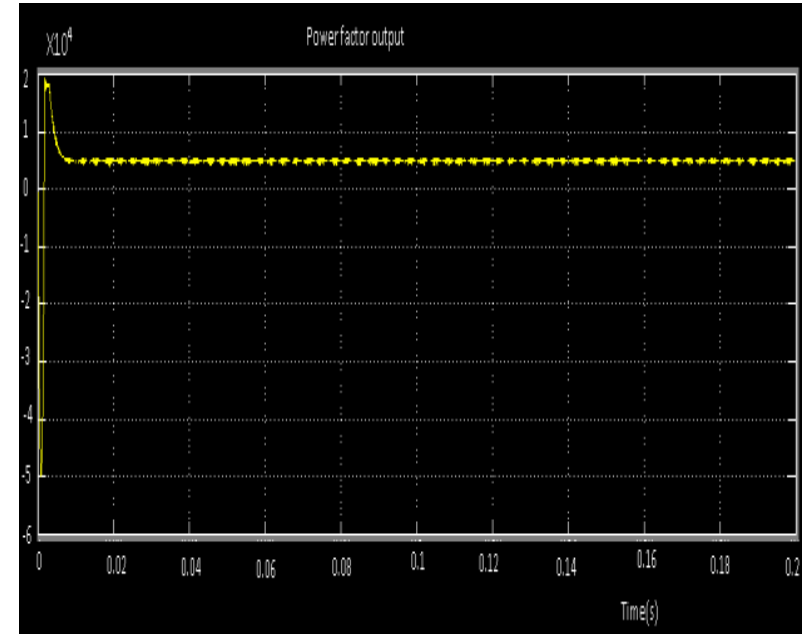

Fig.8.Power Factor Output

Fig.8 represents the constant power factor output when any one of the source is in OFF condition. The conditions are i) When Wind-ON,PV-OFF,Diesel-ON, ii) Wind-OFF,PVON,Diesel-ON and iii) Wind-ON,PV-ON,Diesel-OFF.

\section{CONCLUSION}

In this proposed method combined sources of solar, wind and Diesel were considered. Since the solar and wind are naturally available then for the generation of power these two sources acts as a primary source. A diesel system also acts as one of the source but the priority given for the natural sources. When any one of the source is cut off then the other two sources were active and the produced power distributed to the load. For the emergency occasions battery back up is provided. In this proposed work solar, wind using PMSG and diesel systems are simulated using MATLAB SIMULINK and thereby constant power factor is maintained when any one of the source is not available.

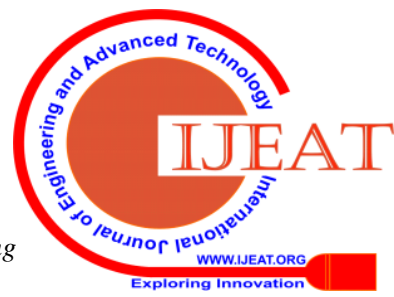




\section{REFERENCES}

1. Krishan kanth, Chinmay Jain and Bhim Singh, "A Hybrid DieselWind-PV based energy generation system with brushless generators",IEEE Transactions of Industrial informatics vol.13,no.4,pp.1713-1721,August 2017.

2. Vinatha U,Vittal K.P, "Grid Integration of wind and photovoltaic hybrid energy system", Journal of Electrical Engineering,pp.1-6.

3. Shashi Kala Kumari, Rekha Jha, "Modelling Simulation and Performance Analysis of Hybrid Power Generation System", International Journal of Innovative Research in Science Engineering and Technology, vol.4, no.7,pp.5838-5843, July 2015.

4. B.Wu.Y.Lang, N.Zargari and S.Kouro, "Power Conversion and Control of Wind energy systems", Hoboken, NJ, Wiley, 2011.

5. R.Pena, R. Cardenas ,J.Proboste, J.Clare and G.Asher, "Wind-diesel generation using doubly fed induction machines", IEEE Transaction on Energy Convers, vol.23 , no.1,pp.201-215,March 2008.

6. D.G.Infield, N.H.Lipman ,G.W.Slack, and P.J. Musgrove, "Review of wind diesel strategies", IEEE Proc. APhys.Sci.,Meas.Instrum.,Manage.Educ.Rev., vol.130,no.9 , pp.614618, Dec.1983.

7. Li Wei ,C.Abbey, and G.Joos, "An online control algorithm for application of a hybrid ESS to a wind- diesel System",IEEE Trans,Ind.Electron., vol.57,no.12,pp.3895-3903, Dec 2010.

8. W M Lin ,C M Hong, C H Chen "Neural network based MPPT control of a stand-alone hybrid power generation system", IEEE Trans.Power Electron.,vol.26 , no.12,pp.3570-3580, Dec 2011.

9. M.A.Tankari, M.B.Camara , B.Dakyo and G.Lefebvre, "Use of ultra capacitors and batteries for efficient energy management in wind diesel hybrid system”, IEEE Trans. Sustain. Energy, vol.4 , no.2,pp.413-423, Apr 2013.

10. N.Sinha, D.C.Das and A.K.Roy , "GA based frequency controller for solar thermal diesel wind hybrid energy generation energy storage system", It.J.Electr. Power Energy syst., vol.43,no.1,pp.261-278,Dec 2012.

11. F.Bonanno, A.Consoli, A.Raciti et.al., "Transient analysis of integrated diesel-wind-photovoltaic generation systems", IEEE Trans.Energy Convers., vol.14,no.2,pp.231-237, June 1999.

12. L.Xu.S.Islam, A.A.Chowdhury, D.O.Koval et.al,"Reliabilityevaluation of a wind diesel battery hybrid power system", in Proc. IEEE/IAS Ind. Commercial Power Syst. Tech. Conf., ,pp.2-9,May 2008.

13. J.De Matos, L.Ribeiro, F.E Silva, "Power control in AC isolated micro grids with renewable energy sources and energy storage systems", IEEE Trans. Ind. Electron., vol.62 ,no.6,pp.3491-3497,Jun 2015

14. R-J Wai, C.Y.Lin and Y.R.Chang, "Novel Maximum power extraction algorithm for PMSG wind generation system", IET Elect. Power Appl.,vol.1,no.2,pp.274-284,Mar 2007.

15. K.Tan and S.Islam, "Optimum control strategies in energy conversion of PMSG wind turbine system without mechanical sensors", IEEE Trans. Energy Convers., vol.19 , no.2,pp.391-398, Jun 2004.

16. M.A.Elgendy, Zahawi , D.J.Atkinson, "Assessment of the incremental conductance maximum power point tracking algorithm", IEEE Trans. Sustain. Energy, vol.4 ,no.1,pp.107-116, ,Jan.2013.

17. Lopamudra, Mitra et.al, "Closed loop control of solar powered boost converter with PID Controller", IEEE International Conference on Power Electronics, Drives and Energy Systems ,2014.

18. Jauch, C.; Islam, P .Jensen, S.M. Sorensen, "Design of a wind turbine pitch angle Controller for Power System stabilization," Renewable Energy, vol.32,no.14,pp.2333- 2348, 2007.

19. Vinod K., Joshi R.R and Bansal R.C, "Optimal Control of matrixconverter based WECS for Performance enhancement and efficiency optimization", IEEE Transaction on Energy conversion, vol.24 ,no.1,pp.263-272, ,2009.

20. Saw Ohnmar Oo, Lwin Za Kyin, "Power Conversion model and simulation of grid connected solar and wind hybrid system", American Scientific Research Journal for Engineering Technology and Sciences, vol.26,no.2,pp.218-237, 2016

21. Prakhar Sharma, Pankaj kumar, et.al., "Closed loop Controlled boost converter using a PID controller for solar wind power system installation", International Journal of Engineering and Technology,vol.7,no.2.8 pp.255- 259,2018.

22. Hari Krishna Sabat,Pratap Chandra, "Simulation and Control of a stand-alone pv/wind/battery/diesel generator hybrid power system", International Research Journal of Engineering and Technology, vol.05,no.5, pp.2551-2558,. May 2018.

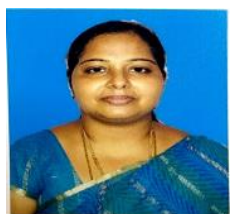

\section{AUTHORS PROFILE}

Bindhu. V. S, received her B.E degree in Electronics and Instrumentation Engineering from Noorul Islam College of Engineering under Manonmaniam Sundaranar University and M.E degree in Power Electronics and drives from Easwari Engineering College under Anna University and currently pursuing Ph.D degree in Power System at Noorul Islam Centre for Higher Education. She is currently an Assistant Professor in Electrical Department, Noorul Islam Centre for Higher Education. Her research interests includes Power Electronics, Power System, Electrical machines,etc.

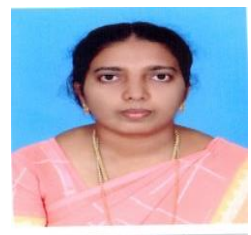

Dr. D. M. Mary Synthia Regis Prabha, is working as an Associate Professor in Noorul Islam Centre for Higher Education in the EEE department. She has completed her BE degree in the year 2001, M.Tech. in 2002 and Ph.D. degree in 2013. She has done her basic degree in the Electrical and Electronics Engineering and M.Tech. degree in Power Electronics and Drives. She is a gold medalist in M.Tech degree. She is having an experience of 17 years in the field of teaching and research activities. Her area of interests includes power electronic converters, controller design, smart grid technologies and power electronic drives. 